\title{
Enhancing the STEM Curriculum Through a Multidisciplinary Approach that Integrates Biology and Engineering
}

\section{Prof. Jennifer Vernengo, Rowan University}

Jennifer Vernengo is an Assistant Professor of Chemical Engineering at Rowan University. Jennifer received her Ph.D. from Drexel University in 2007. She began work as a materials scientist at Synthes Biomaterials, then joined Drexel University College of Medicine as postdoc in 2009. Jennifer two published research papers and one patent in the area of injectable biomaterials for orthopedic tissue replacement and repair. She is particularly interested in developing innovative approaches to biomedical engineering education.

\section{Dr. Stephanie Farrell, Rowan University}

Dr. Stephanie Farrell is an Associate Professor of Chemical Engineering at Rowan University (USA). She obtained her PhD in Chemical Engineering from New Jersey Institute of Technology in 1996. Prior to joining the faculty at Rowan in 1998, she was an Assistant Professor of Chemical Engineering and Adjunct Professor of Biomedical Engineering at Louisiana Tech University until 1998. Dr. Farrell has made contributions to engineering education through her work in experiential learning, focusing on areas of pharmaceutical, biomedical and food engineering. She has been honored by the American Society of Engineering Education with several teaching awards such as the 2004 National Outstanding Teaching Medal and the 2005 Quinn Award for experiential learning.

\section{Dr. Jennifer Kadlowec, Rowan University \\ Dr. Johannes Strobel, Texas A\&M University}

Dr. Johannes Strobel is Director, Educational Outreach Programs and Associate Professor, Engineering and Education at Texas A\&M. After studying philosophy and information science at three universities in Germany, he received his M.Ed. and Ph.D. in Learning Technologies from the University of MissouriColumbia. He worked at Concordia University, Montreal and has been the director of the Institute of P-12 Engineering Research and Learning at Purdue University. NSF and several private foundations fund his research. His research and teaching focuses on engineering as an innovation in P-12 education, policy of P-12 engineering, how to support teachers and students' academic achievements through engineering, the measurement and support of the change of 'engineering habits of mind' particularly empathy and the use of cyber-infrastructure to sensitively and resourcefully provide access to and support learning. 


\title{
Enhancing the STEM Curriculum Through a Multidisciplinary Approach that Integrates Biology and Engineering - Module Development
}

\begin{abstract}
Due to the increasing prevalence of cardiovascular and orthopedic disorders in today's modern society, there is a necessity to engineer biomaterials that improve the quality of life for people with painful and debilitating diseases. This will require educational institutions to provide specialized instruction in these areas. Yet, there have been relatively few published reports on biomaterials and tissue engineering-related lab activities, and existing activities lack a foundation in materials science. A primary deliverable of this project is to address this need and thus strengthen science, technology, engineering and math (STEM) education by developing interactive experiments that introduce tissue engineering through a biomaterials design perspective, emphasizing mechanics, cell behavior, and drug delivery. Cutting-edge methods in these fields have been adapted so they can be applied starting at the freshman level through upper level electives in chemical, mechanical, or biomedical engineering and cellular/molecular biology. The anticipated results of the project will be i) the implementation of curricular materials that fulfill a need in STEM education, ii) increased student interest in pursuing undergraduate and graduate study in STEM disciplines, iii) higher student retention in science and engineering majors, iv) and the development of a well-rounded workforce of engineers prepared to find multidisciplinary engineering solutions to the growing health care needs of the world.
\end{abstract}

\section{INTRODUCTION}

Biomaterials have received considerable attention over the past 30 years. A biomaterial has been defined as a material intended to interface with a biological system to evaluate, augment, or replace any tissue organ or function in the body ${ }^{1,2}$. Therefore, the field of biomaterials encompasses the study of materials science, medicine, and biology. Biomaterials are a large portion of the healthcare market and represent a 9 billion dollar per year industry ${ }^{3}$. It is estimated that over 11 million people have implants utilizing engineered biomaterials ${ }^{4}$. Still, more recent advances in the field have focused on designing materials that help to repair tissue, not just replace it. These biomaterials, referred to as tissue engineering scaffolds, are often multifunctional in nature, or have the ability to deliver simultaneously the biochemical and cellular factors necessary to promote healing. For this reason, cell-material interactions and drug delivery have become integral aspects of biomaterials research.

The clinical need for biomaterials will require educational institutions to provide specialized instruction in these areas ${ }^{5}$. In fact, biomaterials is one of the twenty-three core topics within bioengineering identified by the Vanderbilt, Northwestern, Texas, and HarvardMIT (VaNTH) Engineering Research Center (ERC) funded by NSF ${ }^{6}$. Despite the importance of the field, there are a very limited number of literature articles published on biomaterials education since the 1990s ${ }^{5,7-13}$. Notably, VaNTH ERC established a taxonomy, or list of core competencies, within the area of biomaterials that educators should cover ${ }^{14}$. On this list of core competencies are i) the fundamentals of materials science, ii) methods of characterizing material properties, and iii) polymer synthesis and characterization. Obviously, materials design is an 
integral part of the field, yet the few existing educational modules related to biomaterials tend to focus biological performance and evaluation.

This project aims to develop hands-on educational activities related to tissue engineering that are materials-centered and applicable to a range of student levels and STEM disciplines. The hands-on experiments cover the application of polymer design to: i) static and dynamic structure-property relationships in hydrogels for load-bearing tissue replacement, ii) cellbiomaterial interactions in tissue engineering scaffolds, iii) characterization of stimuli-responsive hydrogel composites, and iv) modeling of mass and heat transfer in thermally sensitive polymer networks for pulsatile drug delivery.

\section{PROJECT GOALS}

The goals and objectives of this project are outlined below.

- To develop multidisciplinary curricula on tissue engineering and biomaterials, based in materials science, that enhances student knowledge of fundamental concepts in core STEM disciplines.

- To generate detailed experimental designs that can be disseminated and adapted by other faculty at 4-year universities on a national level.

- To increase retention and recruitment into STEM disciplines, especially among underrepresented groups.

\section{MODULES}

The project encompasses four focus areas, each composed of several scalable experiments, which use biomaterials science and tissue engineering as a vehicle through which undergraduates will learn core STEM principles. The multidisciplinary experiments are applicable to chemical, mechanical, biomedical and materials engineering programs, as well as biological sciences. Each group of experiments will be designed such that they can be applied at various levels in undergraduate STEM education, at increasing levels of complexity. For instance, at the freshman level, the experiments will be adapted such that they involve basic engineering calculations and methods of data analysis. When applied at upper levels, students will investigate the same problem by looking at variables affecting biomaterial performance and applying advanced concepts, such as transport phenomena, mechanics, and modeling simulations.

\subsection{Module 1: Structure-property relationships in hydrogels}

The meniscus is a crescent-shaped pad of cartilage that disperses stress during loading of the knee joint. Menisectomies are performed when the tissue is damaged beyond repair, most often the result of car accidents or sports injuries ${ }^{15}$. The patients who receive this procedure are usually young and active. In order to get them mobilized and rehabilitated as soon as possible, the best option may be to replace the meniscus with an artificial biomaterial. In order to prevent future degenerative changes in the joint, the optimal meniscus replacement would have similar compressive mechanical and viscoelastic behavior to the natural meniscus. In this challengebased series of lessons, students will prepare and evaluate hydrogels as an artificial meniscus. 
Named 'Biomaterial of the Month' in 2007 by the Society for Biomaterials, a hydrogel is a threedimensional water swollen network composed of crosslinked hydrophilic polymer chains ${ }^{3}$. Students will prepare and characterize their own hydrogels composed of poly(vinyl alcohol)

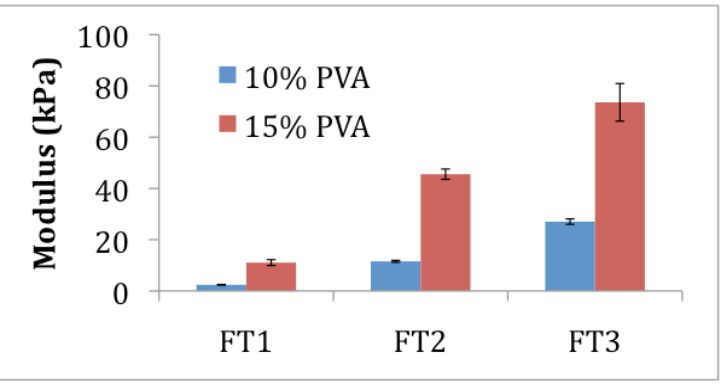

Figure 1. Unconfined compressive modulus of PVA hydrogels formed from 10 and $15 \%$ w/v aqueous solutions after 1, 2, and 3 freeze-thaw cycles (FT1, FT2, and FT3, respectively).
(PVA). This material was chosen because it has been investigated for cartilage replacement ${ }^{15-18}$ and it is safe, easy to prepare, and cost effective to purchase. Physically crosslinked hydrogels can be prepared from freeze-thaw cycles of aqueous solutions of PVA ${ }^{19-21}$. Researchers who have studied the formation of PVA hydrogels from freeze-thaw cycles ${ }^{17,22-25}$ have found that the mechanical properties can be varied as a function of the polymer molecular weight, concentration of the aqueous solution, and the number of freezethaw cycles.

At the freshman level, students will prepare their own PVA gels with 3, 4, or 5 freeze-thaw cycles ( 24 hour freeze, 2 hour thaw) and conduct unconfined compressive testing. For these tests, gels will be compressed to $30 \%$ strain at a strain rate of $100 \%$ per minute using a FGS200PV E-Force Test Stand mechanical testing system (located in the College of Engineering). Students will convert load-displacement data to stress-strain data and report the average unconfined compressive modulus for the gels. Sample data for hydrogels formed from 10 and $15 \%$ w/v PVA solutions and 1, 2, or 3 FT cycles is shown in Figure 1. Increasing polymer concentration and increasing number and duration of freeze-thaw (FT) cycles tends to increase the degree of physical crosslinking in the hydrogels ${ }^{17}$, which inhibits chain motion and increases the mechanical properties. This exercise is appropriate for the freshman level because it involves basic engineering calculations, like stress and strain, and allows students to conceptualize how structure can influence mechanical properties.

In upper level chemical or mechanical engineering courses, such as the junior-level Materials Science, students will analyze the mechanical behavior of the hydrogels far more in depth, both experimentally and computationally. They will use an analytical model, the neo-Hookean strainenergy density function, to describe the nonlinear hyperelastic behavior of the hydrogels ${ }^{26}$. They will validate the model by comparing predicted modulus values for intermediate crosslink densities with experimental data. Additionally, viscoelastic properties of hydrogels are important to characterize, especially in load-bearing applications like meniscus replacement. The time-dependent sensitivity of the materials to loads can be determined with stress relaxation and creep tests ${ }^{27,28}$. Native porcine cartilage can be readily obtained from a butcher and tested in parallel with the synthetic hydrogels at all student levels to compare the mechanical behavior. The learning objectives of this module are to teach the students to i) identify key network parameters that affect the mechanical properties of three-dimensional polymer networks, ii) quantify compressive and viscoelastic mechanical properties, iii) use a computational model to predict mechanical properties of a material, and iv) define the role mechanical properties in selecting materials for cartilage repair and replacement. 
Cell-based therapies for cartilage regeneration can involve the use of pluripotent and multipotent (progenitor) stem cells as well as fully differentiated, autologous cells. Learning laboratory techniques for the maintenance and differentiation of these cell types is indispensible in all research that focuses on the repair, restoration, replacement, and/or regeneration of human biological systems. Furthermore, these skills are equally valuable in biological research that investigates biochemical, physiological, cellular and molecular processes. Likewise, it is vital that students faced with tissue engineering problems understand the fundamental properties of cells and how alteration of their environment affects processes that control proliferation, survival and differentiation. In focus area 2, students will apply knowledge of cell biology to design and execute experiments that analyze 1) the growth of Human Embryonic Kidney 293 (HEK293) cells, 2) the differentiation of chondrocytes from multipotent stem cells, and 3) the gene expression changes that occur during cellular differentiation.

In the first unit of focus area 2, student-driven inquiry into cell growth rates in various culture conditions will serve as an introduction to the concepts of cellular proliferation and will build the foundational skills necessary to conduct more advanced cell culturing manipulations and tissue engineering. In addition, students will develop an understanding of how cells respond to environmental conditions such as cell density, nutrient availability and cell-substratum interactions. The HEK293 cell line, which is already grown by Co-PI Cristina Iftode and her undergraduate research students, will be employed to introduce students to cell culture techniques and how cells respond to varying culture conditions. This cell line is especially well suited for this introduction since it is well established, long-lived and easy to grow. Additionally, research students at Rowan University have already optimized some of the proposed assays using these cells. During basic cell culture maintenance of HEK293 cells, students will learn aseptic liquid transfer, medium preparation, counting cells with a hemacytometer, passaging and freezing cells while further developing microscopy skills. Students will design and execute experiments to test influences on cell culture growth and gross cellular morphology by manipulating various culture conditions such as 1) cell seeding density, 2) medium composition (e.g. amounts and types of serum, amino acid supplements, the use of conditioned media), and 3) culture substratum (e.g. cell culture plastic, gelatin, matrigel, polylysine, feeder layers). These inquiry based experiments will require students to become knowledgeable of the fundamental properties of cultured cells as well as develop specific laboratory skills including the production of cell growth curves, assessment of cell viability with LIVE/DEAD assays, analysis of cell proliferation by quantifying DNA amount with PicoGreen, and analysis of cell morphology with basic stains, such as hematoxylin (nucleus), eosin (cytoplasm, collagen) and alcian blue (glycosaminoglycans).

In the second unit of focus area 2, following the development of basic cell culture skills and an understanding of processes which regulate cell activity in culture, students will study cellular differentiation by investigating the differentiation potential and efficiency of mesenchymal stem cells (MSCs) derived from two distinct tissue sources, bone-marrow and adipose tissue. The multilineage differentiation capability (chondrogenic, osteogenic, adipogenic) of adult MSCs as well as the reduced ethical concerns regarding their isolation (compared to embryonic stem cells) 
made them an attractive cell reservoir for applications of tissue engineering and regenerative medicine, including for cartilage repair ${ }^{29}$. We selected the bone marrow- and adipose tissuederived MSCs for several instructional and practical reasons: i) they are the best characterized of all adult MSCs, ii) they manifest different potency for chondrogenesis ${ }^{30,31}$, iii) they differ in their availability, abundance, and morbidity associated with their isolation methods ${ }^{32,33}$, and iv) are available commercially. This comparative analysis will provoke the students to further explore why MSCs from different sources have distinct requirements for chondrogenic differentiation and whether these reflect the existence of origin-specific biological signatures.

Students will design their experimental inquiries to determine how culture conditions alter cell differentiation. Teams of 2-3 students will independently design and execute studies to test how the following influences the formation of differentiated chondrocytes: 1) undifferentiated cell types, and 2) addition of growth factors (e.g, transforming growth factor b (TGF-b) family, bone morphogenic protein (BMP) family, basic fibroblast growth factor (FGF-2), insulin-like growth factor-1, IGF-1). Students will assay cell viability, cell number and differentiation. Each student team will assay differentiation by one of the following 1) biochemical analysis, 2) analysis of gene expression, or 3) histological analysis. For biochemical analysis, students will quantify glycosaminoglycan and collagen content using the dimethylmethylene blue dye (DMMB) assay and the Sircol soluble collagen assay, respectively, in conjunction with a PicoGreen assay to normalize samples to amount of DNA. Analysis of gene expression will be examined by RT-PCR analysis of Sox9, collagen types I and II, cartilage oligomeric matrix protein (COMP) and aggrecan ${ }^{34,35}$, some of the factors known to be expressed by differentiated chondrocytes. Morphological analysis will include staining cells with hematoxylin (nucleus), eosin (cytoplasm), safranin-O (proteoglycans), and fastgreen (collagen). The use of different assays by individual teams will allow discussion of the benefits and limitations of assay methods and exposure to multiple techniques while still keeping each individual project feasible within the setting of a semester-long lab intensive course. Through the analysis of cellular differentiation students will develop cell culture technique abilities, improve microscopy skills, learn techniques for isolation and analysis of nucleic acids, primer design and cell staining. The learning objectives of this module are i) to identify how cell proliferation and differentiation are dependent on cell source and environmental conditions, ii) correlate manipulation of culture conditions to changes in gene expression, iii) design and execute experiments to characterize cell viability and differentiation, and iv) develop proficiency in cell culture.

\subsection{Module 3: Tissue engineering- Ear to the future}

Recent advances in the field of regenerative medicine have led to tissue engineering therapies involving hydrogels for the treatment of degenerated and injured tissue. These approaches involve growing tissue or organs by encapsulating cells in hydrogels to mimic the in vivo arrangement of cells ${ }^{36}$. The cells then produce new tissue with identical structure and properties to native tissue. Eventually, the hydrogel may degrade away, leaving behind the newly formed tissue. This challenge-based series of experiments will be introduced within the framework of a recent article in the Akron Beacon Journal Times ${ }^{37}$ concerning a 5-year-old with a congenital defect causing an ear deformation. Researchers removed ear tissue from the patient, isolated the cells, and seeded them within a degradable polymeric scaffold in the shape of an ear. The cells grew new ear tissue, which could eventually be implanted into the patient. 
In this activity, students will be approached with the question, "How did they re-grow the ear cartilage?" Students will prepare their own tissue engineering scaffolds and characterize the behavior of encapsulated cells within the material. The polymer used in this study is alginate, which has been used extensively in a variety of tissue engineering applications ${ }^{38-42}$. Alginate hydrogels are easy to prepare due to gelation of the aqueous solutions of the polymer in the presence of divalent ions such as calcium. It is straightforward to encapsulate cells within alginate networks by suspending them in aqueous solutions of alginate prior to crosslinking with calcium $^{43,44}$. K-12 students will begin their exploration of alginate gels by forming them from alginate solutions with food coloring and calcium chloride ${ }^{43,44}$. The students will gain an appreciation for the feel of hydrogels and how they can be used to replace soft tissues in the body. In addition, we want them to be able to visualize encapsulation of cells in hydrogels and how it is akin to tissues in the body acting as a 3D framework for our native cells. For this activity, yeast cells, Saccharomyces cervisiae, will be substituted for cells typically used in cartilage tissue engineering, such as chondrocytes or mesenchymal stem cells. Yeast is a commonly used model organism, and has been proposed before in K-12 outreach activities on tissue engineering ${ }^{8}$. Students will suspend the yeast cells in alginate solutions prior to crosslinking. Upon slicing the hydrogels, the yeast cells can be visualized with a simple light microscope.

At upper levels, junior and senior students will characterize the behavior of encapsulated chondrocytes in the alginate matrices. In order to do so, the students will build on the cell culture skills that they developed in focus area 2. The outline for this experiment was

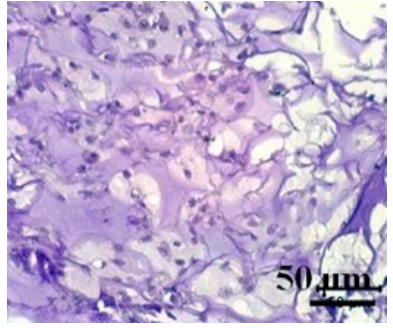

Figure 2. Hematoxylin and eosin staining of chondrocytes encapsulated inside alginate scaffolds. adapted from several cartilage tissue engineering research studies using alginate $35,44-47$. Alginate solutions will be steam sterilized in an autoclave and used to encapsulate adult bovine chondrocytes, which will be isolated and expanded by the instructor by well established methods 48. The cell-biomaterial constructs will be cultured for 7-14 days. After this period, the scaffolds will be fixed with paraformaldehyde, dehydrated by sequential ethanol incubations, embedded in paraffin blocks, sectioned with a microtome and placed on slides, deparaffinized and then stained with hematoxylin to visualize nucleic acids, eosin for proteins, including collagen expressed by the chondrocytes, and alcian blue to highlight glycosaminoglycans. A sample image for alginate-encapsulated chondrocytes, reproduced from Wang et al. ${ }^{46}$, is shown in Figure 2 . The educational objectives of this focus area are to teach students to i) identify the specialized functions of the cells, such as the synthesis of molecules, ii) identify the role of cells in tissue engineering, iii) design and execute a basic experiment for determining cell viability and biochemical characterization of cell-biomaterial constructs.

3.4 Module 4: Can hydrogels fix a broken heart? Environmentally responsive polymers in drug delivery

Hydrogels can exhibit changes in their water content, network structure, and mechanical strength in response to different stimuli, such as $\mathrm{pH}^{49}$, temperature ${ }^{50}$, and electric current ${ }^{51}$. Many times, these stimuli can be used to modulate drug release and even deliver it in a pulsatile fashion. In this focus area, we aim to show students the mechanisms by which responsive polymer systems work and how they can be used to engineer drug delivery systems that meet 
clinical needs. As a challenge-based strategy, this unit will be introduced within the framework of a clinic need for a better treatment of coronary thrombosis, or a blood clot in one of the arteries, which causes a heart attack. In these situations, anticoagulants would ideally only be delivered at the site of the blood clot when it occurs, rather than administered systemically. The risk associated with systemic delivery is that the patient could undergo excessive bleeding. It is also known that small fluctuations in temperature and $\mathrm{pH}$ occur in the vicinity of blood clots. In this set of experiments, students will be approached with the question, "How can environmentally-sensitive biomaterials be used to treat heart attacks by delivering anticoagulants locally and only when a clot occurs?"

Pulsatile drug delivery has been achieved from magnetic biomaterials by the application of high frequency alternating magnetic field (AMF). AMF has the potential to permeate tissue with negligible impact on the body ${ }^{52}$. Satarkar et al. ${ }^{53}$ developed a magnetic system based on poly(N-isopropylacrylamide) (PNIPAAm) hydrogels. PNIPAAm has been investigated extensively in biomedical areas because its aqueous solutions have lower critical solution temperature (LCST), typically between $32^{\circ} \mathrm{C}$ and $37^{\circ} \mathrm{C}^{54-57}$. Below this temperature, PNIPAAm is hydrophilic, so the polymer chains remain in an expanded state in the presence of water. Above that temperature, the polymer becomes hydrophobic, so the chains collapse, resulting in a water/volume loss of the gel and a transition from transparent to opaque white. This transition serves as a convenient on-off switch for the delivery of therapeutics, thus PNIPAAm has been extensively investigated for applications such as protein delivery ${ }^{58-61}$.

We produce PNIPAAm polymers in our laboratory regularly, and it can be achieved with a straightforward free-radical polymerization of NIPAAm monomer in water using a redox initiator ${ }^{26}$. The hydrogel can be made magnetic by suspending magnetic $\mathrm{Fe}_{3} \mathrm{O}_{4}$ powder in aqueous solutions of PNIPAAm, below the LCST. Upon application of a magnetic field with a solenoid, the presence of the magnetic particles will cause the solution to heat above the LCST, causing collapse of the polymer around the magnetic particles and the squeezing out of the drug. A pulsatile release profile can be generated by turning on and off the magnetic field ${ }^{53}$. The K12 students will see a demonstration of the activity, since the transition of the hydrogel from transparent to opaque is visually quite striking. This will be an opportunity for them to learn and apply principles of electricity and magnetism. Also, the idea of drug delivery can be conveyed by incorporating yellow food dye in the polymer, and watching its diffusion into release medium by an increase in color intensity with each pulse.

At the freshman level, students will build their own AMF device using a power supply and solenoid ${ }^{53,62}$. They will generate quantitative pulsatile swelling and release profiles for a model protein, bovine serum albumin, by varying the magnitude and duration of the AMF. The application of AMF causes heating of the hydrogel above the LCST, resulting in chain collapse and loss of water. For upper level students, this experiment can be adapted to junior-level chemical engineering courses, Process Heat and Mass Transfer. The mass transfer coefficient $(h)$ of molecules through the polymer network can be determined using a two-phase mass transfer model ${ }^{63}$. Regressing the theoretical curve produced by this model to experimental data at temperatures above and below the transition temperature will enable students to determine $h$ as a function of polymer network structure. Students will also conduct mathematical modeling and simulation of the heat transfer processes involved with heating the polymer network from the 
magnetic particles. The objectives of this focus area are to teach students to i) identify how stimuli-responsive delivery systems work and their potential applications, ii) build a remotely controlled drug delivery system using magnetic particles and an alternating magnetic current, iii) use the system as a test-bed for the application of fundamental mass and heat transfer principles.

\section{EVALUATION PLAN}

Summative and formative project evaluation will be carried out according to the recommended practices of the National Science Foundation ${ }^{64}$. The following instruments will be used as a formative assessment of whether the project is meeting its goals.

- Pre and post-tests: The questions (written and collected by PI) will be mapped to ABET and NCSES learning outcomes for pre-college and undergraduates.

- Rubrics: For each experiment, the undergraduate students will design an experimental plan, state what measurements will be made, and how they will analyze and interpret the data. On lab reports and oral presentations, students will be graded with respect to how well they document, execute, and communicate their results. These outputs will be graded with rubrics (written and collected by PI) mapped to learning outcomes from ABET.

- $\quad$ Student pre and post-surveys and course evaluations: Pre and post-surveys before and after each experiment will probe achievement of project goals, such as improved attitudes towards STEM areas and the building of confidence in conducting research ${ }^{65}$. These instruments have been developed by an external evaluator and will be collected by PI.

- Course evaluations: The standard questionnaire administered by Rowan will be collected by the course instructor and will serve to provide student feedback on the experiments. Data will be collected by PI.

- Surveys of K-12 educators and other partners: Reflective journals and surveys that measure teachers' self-efficacy, concerns on adoption of the modules, and their students' career aspirations towards engineering and perceived impact on students' knowledge and attitudes will be administered. These instruments have been tested and validated by INSPIRE (external evaluator) and will be collected by PI. They may be administered via the web repository. The number of outreach events and attendance at each event will be tracked.

A summative evaluation will be conducted with the following instruments:

- Career aspiration survey for undergraduate students: This survey (modified, tested, and validated by the external evaluator) will be used to assess the long-term impact of the curricula on student interest in bioengineering, and the impact on their career choices, such as the decision to go to graduate or medical school.

- Faculty and department chairs: The PI will track enrollment in bioengineering concentration, number of courses impacted by the project, and number of Rowan students who participated in the experiments. Department chairs will conduct senior exit interviews to track retention/graduation rates and supplement data from career aspiration surveys. Data will be collected by PI. 
The assessment methods are summarized in the logic map shown in Table 1.

Table 1. Logic map for project evaluation.

\begin{tabular}{|c|c|c|c|c|c|}
\hline \multirow{2}{*}{ Inputs } & \multirow{2}{*}{ Activities } & \multirow{2}{*}{ Outputs } & \multicolumn{2}{|c|}{ Measurable Outcomes } & \multirow{2}{*}{$\begin{array}{c}\text { Assessment } \\
\text { methods }\end{array}$} \\
\hline & & & Short term & Long term & \\
\hline $\begin{array}{l}\text { - PI and co- } \\
\text { PIs } \\
\text { - Rowan } \\
\text { students } \\
\text { - Outreach } \\
\text { partners } \\
\text { - Evaluators }\end{array}$ & $\begin{array}{l}\text { - Develop } \\
\text { experiments in } \\
\text { four focus } \\
\text { areas } \\
\text { - Institutionalize } \\
\text { into core } \\
\text { curricula at } \\
\text { Rowan } \\
\text { - Incorporate } \\
\text { into outreach } \\
\text { activities } \\
\text { - Collect } \\
\text { evaluation data } \\
\text { at Rowan }\end{array}$ & 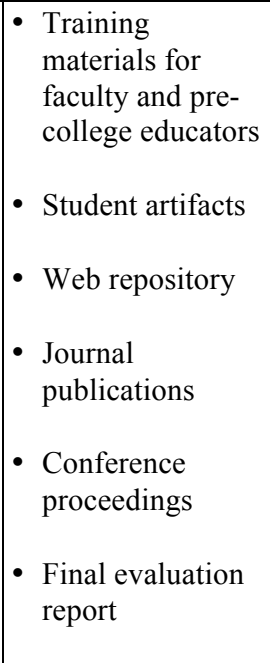 & $\begin{array}{l}\text { - Achieved learning } \\
\text { outcomes by students } \\
\text { - Improved adaptive } \\
\text { expertise } \\
\text { - Faculty and pre-college } \\
\text { educators trained to deliver } \\
\text { curricula } \\
\text { - Improved attitudes and } \\
\text { interest in STEM } \\
\text { - Improved confidence in } \\
\text { engineering design } \\
\text { - No. of outreach events and } \\
\text { attendance } \\
\text { - No. students in } \\
\text { bioengineering } \\
\text { concentration } \\
\text { - Increased participation by } \\
\text { underrepresented groups }\end{array}$ & $\begin{array}{l}\text { - No. of courses } \\
\text { permanently } \\
\text { impacted at } \\
\text { Rowan } \\
\text { - Improved } \\
\text { graduation rates } \\
\text { - Adoption of } \\
\text { curricula locally } \\
\text { and nationally } \\
\text { - Increased retention } \\
\text { in engineering } \\
\text { - Increased interest } \\
\text { in graduate or } \\
\text { medical school } \\
\text { - Increased career } \\
\text { interest in } \\
\text { biomedical } \\
\text { engineering }\end{array}$ & 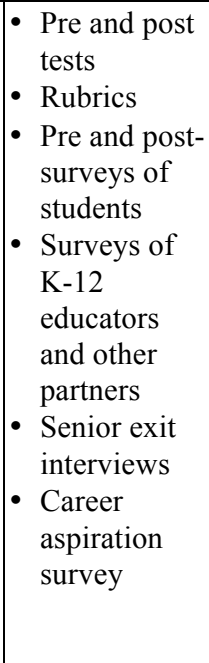 \\
\hline
\end{tabular}

\section{ACKNOWLEDGEMENT}

This material is based upon work supported by the National Science Foundation under Grant No. 1245595.

\section{REFERENCES}

1. Williams D. The Williams Dictionary of Biomaterials. Liverpool: Liverpool University Press; 1999.

2. Polymer Characterization Techniques.247-56.

3. Ratner B, Hoffman AS, Schoen FJ, Lemons JE. Biomaterials Science: A

Multidisciplinary Endeavor. Biomaterials Science: A Introduction to Materials in Medicine. San Diego: Elsevier Academic Press; 2004. p. 1-9.

4. Moss A. Use of Selected Medical Device Implants in the United States. Hyattsville, MD: National Center of Health Statistics, 1988.

5. Black J, Shalaby SW, LaBerge M. Biomaterials Education: An Academic Viewpoint. Journal of Applied Biomaterials. 1992;3:231-6.

6. Vanderbilt N, Texas, and Harvard-MIT Engineering Research Center.

http://www.vanth.org/curriculum/curr bio domains.asp.

7. Saterbak A, editor Laboratory Courses Focused on Tissue Engineering Applications Proceedings of the 2002 American Society for Engineering Education Annual Conference \& Exposition; 2002.

8. Pittsburg Tissue Engineering Initiative I. An Education Outreach Manual in Tissue Engineering. In: Pittsburg Uo, editor. 2010.

9. Birol G, Liu S, Smith D, Hirsch P Educational Modules in Tissue Engineering Based on the "How People Learn" Framework. Bioscience Education E-journal. 2006;7. 
10. Bhatia S. A disease-centered approach to biomaterials education and medical device design. 33rd Annual International Conference of the IEEE EMBS; Boston, Massachusetts2011. p. 3617-9.

11. Reichert W, Harris TR, Lemmons J, Mikos AG, Puleo DA, Schoen FJ, Temenoff JS. 2011 Panel on developing a biomaterials curriculum. Journal of Biomedical Materials Research Part A. 2011;100A:802-16.

12. Feldman D, Gombotz WR. Biomaterials Education: An academic and industrial viewpoint. Journal of Applied Biomaterials. 1991;2:133-9.

13. Burny F, Donkerwolcke M, Muster D. Biomaterials education: A challenge for medicine and industry in the late 1990s. Material Science and Engineering Part A. 1995;199:53-9.

14. Vanderbilt N, Texas, and Harvard-MIT Engineering Research Center. http://www.vanth.org/curriculum/Curr taxon.asp.

15. Kobayashi M, Chang YS, Oka M Masanori Kobayashia. A two year in vivo study of polyvinyl alcohol-hydrogel (PVA-H) artificial meniscus Biomaterials. 2005;26(16):3243-8.

16. Spiller K, Laurencin SJ, Lowman AM. Characterization of the Behavior of Porous Hydrogels in Model Osmotically-Conditioned Articular Cartilage Systems. Journal of Biomedical Materials Research Part B: Applied Biomaterials. 2009;90B:752-9.

17. Stammen J, Williams S, Ku DN, Gulderg RE. Mechanical properties of a novel PVA hydrogel in shear and unconfned compression. Biomaterials. 2001;22:799-806.

18. Spiller. Semi-degradable, Multi-functional Hydrogelsfor the Repair of Articular Cartilage Defects. Philadelphia, PA: Drexel University; 2010.

19. Peppas N, Merrill EW. Crosslinked poly (vinyl alcohol) hydrogels as swollen elastic networks. Journal of Applied Polymer Science. 1977;21:1763-77.

20. Thomas J, Lowman A, Marcolongo M. Novel associated hydrogels for nucleus pulposus replacement. J Biomed Mater Res Part A. 2003;67:1329-37.

21. Hassan C, Stewart JE, Peppas NA. Diffusional characteristics of freeze/thawed poly(vinyl alcohol) hydrogels: Applications to protein controlled release from multilaminate devices. European Journal of Pharmaceutics and Biopharmaceutics 2000;49:161-5.

22. Stauffer S, Peppas NA. Poly(vinyl alcohol) hydrogels prepared by freezing-thawing cyclic processing. Polymer. 1992;33(18):3932-6.

23. Urushizaki F, Yamagushi H, Nakamura K, Numajiri S, Sugibayashi, K, Morimoto Y. Swelling and mechanical properties of poly(vinyl alcohol) hydrogels. International Journal of Pharmaceutics 1990;58:135-42.

24. Hickey A, Peppas NA. Mesh size and diffusive characteristics of semicrystalline poly (vinyl alcohol) membranes prepared by freezing/thawing techniques. Journal of Membrane Science 1995;107:229-37.

25. Peppas N, Scott JE. Controlled release from poly (vinyl alcohol) gels prepared by freezing-thawing processes. Journal of Controlled Release 1992;18:95-100.

26. Kubinski P, Wiltsey C, Christiani T, Kadlowec J, Vernengo J. Characterization of Injectable Hydrogels Based on Poly(N-isopropylacrylamide)-g-chondroitin sulfate with Adhesive Properties for Nucleus Pulposus Tissue Engineering. Submitted to Journal of Materials Science: Materials in Medicine. February 2012.

27. Callister W. Material Science and Engineering: An introduction: John Wiley \& Sons Inc; 1995. $852 \mathrm{p}$. 
28. Cloyd J, Malhotra NR, Weng L, Chen W, Mauck RL, Elliott DM. Material properties in unconfined compression of human nucleus pulposus, injectable hyaluronic acid-based hydrogels and tissue engineering scaffolds. Eur Spine J (2007) 16:1892-1898. 2007;16:1892-8.

29. Tuan R, Boland G, Tuli R. Adult mesenchymal stem cells and cell-based tissue engineering. Arthritis Research and Therapy. 2001;5(1):32-45.

30. Winter A, Breit S, Parsch D, Benz K, Steck E, Hauner H, Weber RM, Ewerbeck V, Richter W. Cartilage-like gene expression in differentiated human stem cell spheroids: a comparison of bone marrow-derived and adipose tissue-derived stromal cells. Arthritis Rheumatism. 2003;48:418-29.

31. Hennig T, Lorenz H, Thiel A, Goetze K, Dickhut A, Geiger F, Richter W. Reduced Chondrogenic Potential of Adipose Tissue Derived Stromal Cells Correlates With an Altered TGFb Receptor and BMP Profile and Is Overcome by BMP-6. Journal of Cellular Physiology. 2007;211:682-91.

32. Illouz Y. Body contouring by lipolysis: a 5-year experience with over 3000 cases. Plast Reconstr Surg. 1983;72:591-7.

33. Locke M, Feiss V, Dunbar R. Concise Review: Human Adipose-Derived Stem Cells: Separating Promise from Clinical Need. Cells. 2011;29:404-11.

34. Hissnauer T, Baranowsky A, Pestka JM, Streichert T, Wiegandt K, Goepfert C, Beil FT, Albers J, Schulze J, Ueblacker P, Petersen JP, Schinke T, Meenen NM, Pörtner R, Amling M. Identification of molecular markers for articular cartilage. Osteoarthritis \& Cartilage. 2010;18(12):1630-8.

35. Herlofsen S, Kuchler AM, Melvik JE, Brinchmann JE. Chondrogenic Differentiation of Human Bone Marrow-Derived Mesenchymal Stem Cells in Self-Gelling Alginate Discs Reveals Novel Chondrogenic Signature Gene Clusters. Tissue Engineering Part A. 2011;17:1003-13.

36. Yang S, Leong K, Du Z, Chua C. The Design of Scaffolds for Use in Tissue Engineering. Part I. Traditional Factors. Tissue Engineering. 2001;7(6):679-89.

37. Powell C. Ear to the Future: Donated Cell Transform from Lab to Mouse. Akron Beacon Journal Times. 2011.

38. Gruber H, Fisher E, Desai B, Stasky A, Hoelscher G, Hanley E. Human intervertebral disc cells from the annulus: three dimensional culture in agarose or alginate and responsiveness to TGF-beta1. Experimental Cell Research. 1997;235(1):13-21.

39. Kulseng B, Skjåk-Braek G, Ryan L, Andersson A, King A, Faxvaag A, Espevik T. Transplantation of alginate capsules. Transplantation. 1999;67:978-84.

40. Prang P, Muller R, Ejaouharib A, Hechmann K, Kunz W, Weber T, Faber C, Vroemen $\mathrm{M}$, Bogdahn U, Weidnera N. The promotion of oriented axonal regrowth in the injured spinal cord by alginate-based anisotropic capillary hydrogels. Biomaterials. 2006;27(19):3560-9.

41. Ribeiro C, Barriasa CC, Barbosa MA. Calcium phosphate-alginate microspheres as enzyme delivery matrices. Biomaterials. 2004;25:4363-73.

42. Wang N, Adams G, Buttery L, Falcon FH, Stolnick S. Alginate encapsulation technology supports embryonic stem cellsdifferentiation into insulin-producing cells. Journal of Biotechnology. 2009; 144:304-12.

43. Cathell M. Alginate gel I: how chemistry affects solubility. Drexel University GK-12 program, Engineering as a Contextual Vehicle for Science and Mathematics Education, 2007.

44. Kuo C, Ma PX Ionically crosslinked alginate hydrogels as sca!olds for tissue engineering: Part 1. Structure, gelation rate and mechanical properties. Biomaterials. 2001;22:511-21. 
45. Schneider N, Lejeune JP, Deby C, Deby-Dupont GP. Viability of equine articular chondrocytes in alginate beads exposed to different oxygen tensions. The Veterinary Journal. 2004;168(2):167-73.

46. Wang C, Yang KC, Lin KH, Liu YL, Liu HC, Lin FH. Cartilage regeneration in SCID mice using a highly organized three-dimensional alginate scaffold. Biomaterials.

2012;33(1):120-7.

47. Willem J, Marinjissen JCM, van Osch G, Aigner J, Verwoerd-Verhoe HL, Verhaar J Tissue-engineered cartilage using serially passaged articular chondrocytes. Chondrocytes in alginate, combined in vivo with a synthetic (E210) or biologic biodegradable carrier (DBM). Biomaterials. 2000;21(6):571-80.

48. Katoh Y, Takayama S Isolation of purified chondrocytes. Methods in Cell Science. 1980;6(3-4):103-5.

49. Lowman A, Morishita M, Kajita M, Nagai T, Peppas NA. Oral delivery of insulin using pH-responsible complexation gels. Journal of Pharmaceutical Science. 1999;88:933-6.

50. Vernengo J, Fussell GW, Smith NG, Lowman AM. Evaluation of novel injectable hydrogels for nucleus pulposus replacement. Journal of Biomedical Materials Research Part B: Applied Biomaterials. 2008;84B(1):64-9.

51. Kim S, Lee CK, Lee YM, Kim IY, Kim SI. Electrical / pH-sensitive swelling behavior of polyelectrolyte hydrogels prepared with hyaluronic acid-poly(vinyl alcohol) interpenetrating polymer networks. Reactive and Functional Polymers. 2003;55:291-8.

52. Andraw W, Nowak H. Magnetism in Medicine. Berlin: Wiley-VCH; 1998.

53. Satarkar N, Hilt Z. Magnetic hydrogel nanocomposites for remote controlled pulsatile drug release. Journal of Controlled Release. 2008;130:246-51.

54. Schild H. Poly(N-isopropylacrylamide): experiment, theory and application. Progress in Polymer Science. 1992;17:163-249.

55. Otake K, Inomata H, Konno M, Saito S. Thermal Analysis of the Volume Phase Transition with N-Isopropylacrylamide Gels. Macromolecules. 1990;23:283-9.

56. Heskins M, Guillet E. Solution properties of poly(N-isopropylacrylamide). Journal of Macromolecular Science, Chemistry. 1969;2(8):1441-55.

57. Costa $\mathrm{O}$, Freitas R. Phase behavior of poly(N-isopropylacrylamide) in binary aqueous solutions. Polymer. 2002;43:5879-85.

58. Milasinovi M, Kalagasidis M, Knezevic-Jugovi Z, Filipovi J. Hydrogels of Nisopropylacrylamide copolymers with controlled release of a model protein. International Journal of Pharmaceutics. 2010;383:53-61.

59. Temtem M, Barroso T, Casimiro T, Mano JF, Aguiar-Ricardo A. Dual stimuli responsive poly(N-isopropylacrylamide) coated chitosan scaffolds for controlled release prepared from a non residue technology. Journal of Supercritical Fluids. 2012;66:398-404.

60. Lu S, Liu M, Ni B. Degradable, injectable poly(N-isopropylacrylamide)-based hydrogels with low gelation concentrations for protein delivery application. Chemical Engineering Journal. 2011;173(1):241-50.

61. Wu J, Liu S, Heng PW, Yang Y. Evaluating protein release from, and their interactions with, thermosentive poly(N-isopropylacrylamide) hydrogels. Journal of Controlled Release. 2005;102:361-72.

62. Kato N, Yamanobe S, Takahashi F. Property of magneto-driven poly (Nisopropylacrylamide) gel containing $\mathrm{Fe}(2) \mathrm{O}(3)$ in $\mathrm{NaCI}$ solution as a chemomechanical device. Material Science and Engineering Part C. 1997;2:141-7. 
63. Lewinska D, Rosinski S, Hunkeler D, Poncelet D, Werynski A. Mass transfer coefficient in characterization of gel beads and microcapsules. Journal of Membrane Science. 2002;209:533-40.

64. Frechtling J, Mark MM, Rog DJ, Thomas V, Frierson H, Hood S, Hughes G, Johnson E The 2010 User Friendly Handbook for Project Evaluation. The National Science Foundation, Division of Research and Learning in Formal and Informal Settings, 2010.

65. Carberry A, Ohland M, Lee HS. Measuring engineering design self-efficacy. Journal of Engineering Education. 2010;99(1):71-9. 